\title{
LABOUR PRODUCTIVITY IN THE REGIONS OF LATVIA
}

\author{
Daina Znotina, Elita Jermolajeva \\ Daugavpils University (Latvia)
}

\begin{abstract}
Labor productivity directly describes return on the labor force or contributed labor and its efficiency. Its calculation is based on the actual output per unit of contributed labor. Labor productivity can be calculated on the level of a company, branch, certain territory, state, etc.

As regards the use of human capital Latvia is one of the leading countries in Central and Eastern Europe; however, in case of Latvia employment does not mean high productivity of human capital. In 2008 in Latvia productivity per one employed person was $51.3 \%$ from the respective indicator in the European Union. In Estonia this indicator was $64.7 \%$, in Lithuania $-61.3 \%$. The lowest indicators of productivity in the European Union were among the newest Member States - Bulgaria 36.5\%, Romania - 47.7\%. In 2008 the highest indicators of productivity were in Luxemburg - exceeding the average rate by $72.8 \%$, Ireland - by $31.5 \%$, and Belgium - by $24.3 \%$.

In the context of aging society, which is very topical problem in Latvia, it is essential to pay attention to increase labor productivity timely. As it is emphasized in the Sustainable Development Strategy of Latvia till 2030 aging of society is related to the loss of labor productivity and changes in the structure of the labor force. If in the nearest years the productivity of human capital is not sufficiently improved, further investments in the basic value and use of human capital will be useless. The most significant opportunity for development in Latvia in the context of demographic burden and changes is facilitation of labor force participation and economic activity, as well as investments in education of population of all age groups and increasing productivity of human capital. Along with traditionally involved educational institutions the activities and services of libraries, cultural education institutions and creativity and interest groups can be give a significant contribution in this field.

Latvia has significant differences in regional development. Considering GDP per capita and assuming that the average indicator in the state is $100 \%$ in the period of time from 2003 to 2007, in Riga region it exceeds the average indicator and fluctuates within the range from $138.4 \%$ to $143.5 \%$; in Latgale region in the respective period this indicator significantly lags behind the average indicator and is in the range from $46.4 \%$ to $53.4 \%$.

Due to the economic crisis GDP in Latvia, including regions, significantly reduced; the most crucial changes were observed in such branches as construction (drop by over $30 \%$ in comparison to 2008), trade and manufacturing industry (drop by over $25 \%$ in each), transport and communications industry (drop by over $15 \%$ ).
\end{abstract}

Keywords: Gross domestic product, kinds of economic activities, number of employed people, added value, labour productivity, regions of Latvia.

\section{Introduction}

Labour productivity is an indicator describing the return on the contributed labour. A high employment level in the country is not a guarantee for high productivity or return on labour. As the number of population is decreasing due to a low birth rate and a high migration rate, which is a topical problem in Latvia, it is essential to increase labour productivity. If in the forthcoming years nothing is done in Latvia to improve human capital productivity, further investments in the basic value and use of human capital will be ineffective. Thus, it is significant to research labour productivity by kinds of economic activities in the regions to reveal branches where it is essential to increase labour productivity.

Aim of research is to research labour productivity by kinds of economic activities in the regions of Latvia.

Tasks of research:

- to study the theoretical aspects of labour productivity;

- to characterize labour productivity calculation methodology;

- to calculate labour productivity in the regions of Latvia and analyze the obtained data;

- to consider opportunities for increasing labour productivity.
Research object is labour productivity.

Research period is from 1998 to 2008.

Research methods - monographic and statistical analysis methods.

Novelty of research is authors' calculations of labour productivity and analysis of the obtained data by economic activities in the added value gross domestic product in the regions of Latvia.

\section{Theoretical aspects of labour productivity}

Labour productivity is an indicator of labour efficiency the output in a definite period (year) per one person employed in the state or company. Labour productivity depends on employees' capacity (physical and mental qualities, health, qualification, experience, age, etc.), wish to work (creative attitude towards work and other facilitating conditions), provision with tools (modern facilities and technological equipment, instruments, arrangement of workplace, etc.) (Ekonomikas terminu skaidrojošā vārdnīca [Explanatory dictionary of economic terms]).

Specialists admit that it is hard to define this term ,labour productivity" in a precise way corresponding to all the areas of activity of enterprises, since productivity, in its essence, is 
a measure of efficiency. The labour efficiency of an enterprise is ensured by a well-planned strategy, a perfect labour environment and work organisation, a targeted and efficient use of resources, a solid and loyal team of employees, and effective internal communication (Lāsmens, Tominens, 2007).

Labour productivity is based on the actual output per unit of contributed labour (Gomez -Salvador, Musso, Stocker, Turunen, 2006).

In the economic sense output is a result of production. The result of production, in its turn, can be expressed as a sum of goods or services or both kinds in terms of value or amount depending on the specifics of data or aims of calculation. The total output on the national scale or the result of contributed labour related to other economic factors is gross domestic product (Ulnicāns, 2010).

Interrelationship of employment development and productivity has also been researched by such authors as Buchele, Christiansen (1999), Gordon (1997), Dew-Becker, Gordon (2008).

Human capital, which includes professional knowledge, social skills, health, motivation, values, attitudes, talents, experience and other characteristics is only one of the factors influencing labour productivity (see Fig. 1). The role of human capital in productivity and economic growth can be direct or indirect (Latvija. Pārskats par tautas attīstību [Latvia. Review of national development], 2007). Human capital can influence productivity indirectly by facilitating creation and adoption of technologies. Social capital is also important in the increase of productivity - networks through which human capital is formed, used and awarded. Social institutes have significant role as well, as they encompass the life of population and market activities as well as create a framework where human capital and social capital can lead to different results (Côté, 2001).

The satisfaction of employees with the job can be increased by good working conditions, social guarantees, medium work intensity, and career possibilities (Bite, Muška, 2010).

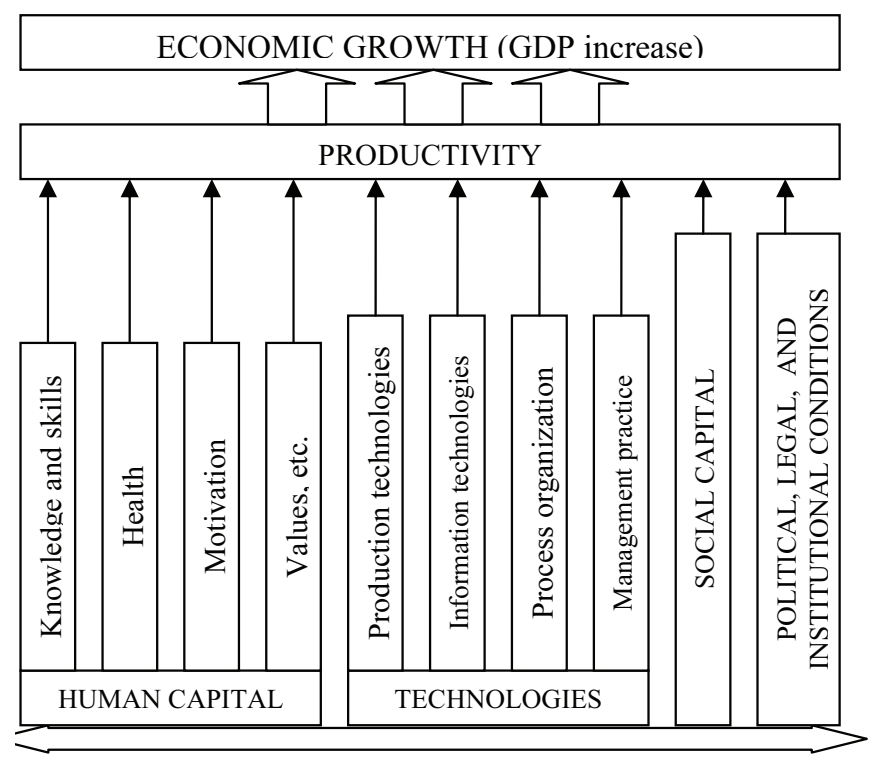

Figure 1. Interaction between human capital, social capital and social institutes

(Latvija. Pārskats par tautas attīstību [Latvia. Review of national development], 2007).

\section{Labour productivity calculation methodology}

Gross domestic product from production approach is calculated as a sum of total added value (at base prices) and product taxes (excluding subsidies) of all kinds of economic activities or institutional sectors (Gross domestic product from production approach).

Total regional value added (VA) is evaluation of a production unit (institution) economic activities in the region. VA in financial terms is determined as a difference between the output of goods and services and the value of intermediate consumption in actual prices of the corresponding year (Total regional value added).

Economic activities take place if specific goods or services are created by adding such resources as equipment, labour force, production technologies, information networks and material resources. Economic activity is described by the products (goods or services) involved in the production process, production process itself and final products (output) (Economic activities according to NACE revision 1.1).

Statistical classification of economic activities in the European Union is done according to the Statistical Classification of Economic Activities in the European Community NACE. Since 2008 the classification of economic activities is done in compliance with the latest NACE version NACE 2. As in the paper the authors research labour productivity in the period of time from 1998 to 2008, there will be applied the classification of economic activities according to NACE revision 1.1 (including year 2008) to make data to be comparable. According to this NACE revision all kinds of economic activities are divided into 17 basic groups: A Agriculture, hunting and forestry, B - Fishing, C - Mining and quarrying, D - Manufacturing, E - Electricity, gas and water supply, F - Construction, G - Wholesale and retail trade; repair of motor vehicles, motorcycles and personal and household goods, $\mathrm{H}$ - Hotels and restaurants, I - Transport, storage and communication, $\mathrm{J}$ - Financial intermediation, $\mathrm{K}$ - Real estate, renting, computer, science and other business activities, L - Public administration and defence; compulsory social security, $\mathrm{M}$ - Education, N Health and social work, $\mathrm{O}-$ Community, social and personal service activities, $\mathrm{P}-$ Activities of households, Q - Extra-territorial organizations and bodies (Statistical classification of economic activities in the European Community, NACE revision 1.1).

In order to calculate labour productivity according to value added by kinds of economic activities in the regions of Latvia, the authors have united economic activities into six groups:

1) Agriculture, hunting and forestry, fishing (A, B),

2) Mining, manufacturing, and related services of these branches $(\mathrm{C}, \mathrm{D}, \mathrm{E})$,

3) Construction (F),

4) Trade, hotels and restaurants, transport, repair and communication services $(\mathrm{G}, \mathrm{H}, \mathrm{I})$,

5) Financial services, real estate transactions ( $\mathrm{J}, \mathrm{K})$,

6) Public administration, community, social and personal services (L, M, N, O, P).

Gross labour productivity on the national scale for a definite period of time is calculated dividing gross domestic product by the number of employed persons (Productivity. The Key to Competitiveness of...). 


\section{Gross productivity $=$ GDP/Number of employed persons}

Calculating labour productivity by kinds of economic activities, product taxes are usually not included into gross domestic product, only total value added of economic activities is taken into consideration.

According to the Order No. 271 "On Statistical Regions in the Republic of Latvia and their Administrative Units" passed by LR Cabinet of Ministers on April 28, 2004 and the Common classification of statistical territorial units in the European Union (NUTS 3), data are calculated on six statistical regions: 1) Riga region; 2) Pieriga region; 3) Vidzeme region; 4) Kurzeme region; 5) Zemgale region; 6) Latgale region (Statistical region).

\section{Analysis of labour productivity in the regions of Latvia}

As regards the use of human capital Latvia is one of the leading countries in Central and Eastern Europe, unfortunately, in the case of Latvia higher employment does not mean higher productivity of human capital (Cilvēkkapitālu mēra kā ...[Human capital is measured as ...]).

In Latvia there are observed significant discrepancies in regional development. Having a look at GDP per capita and assuming that the average national indicator is $100 \%$ in the period of time from 2003 to 2007 (see Fig. 2), it is seen that in Riga region it exceeds the average national indicator and fluctuates from $138.4 \%$ to $143.5 \%$, but in Latgale region during the whole period this indicator significantly lags behind the average national indicator and is between $46.4 \%$ and $53.4 \%$. It proves the high concentration of labour force and economic activities in Riga.

The volume of gross domestic product in Latvia, including regions, has significantly reduced due to the economic crisis. In 2009 the most crucial changes took place in such branches of national economy as construction (volume drop by more than $30 \%$ in comparison to 2008), trade and manufacturing (drop by more than $25 \%$ in each), transport and communication (drop by more than 15\%). In the European Union in 2008 on average in comparison to 2007 GDP increased by $0.8 \%$ (Regínu attīstība Latvijā [Development of regions in Latvia] 2009).

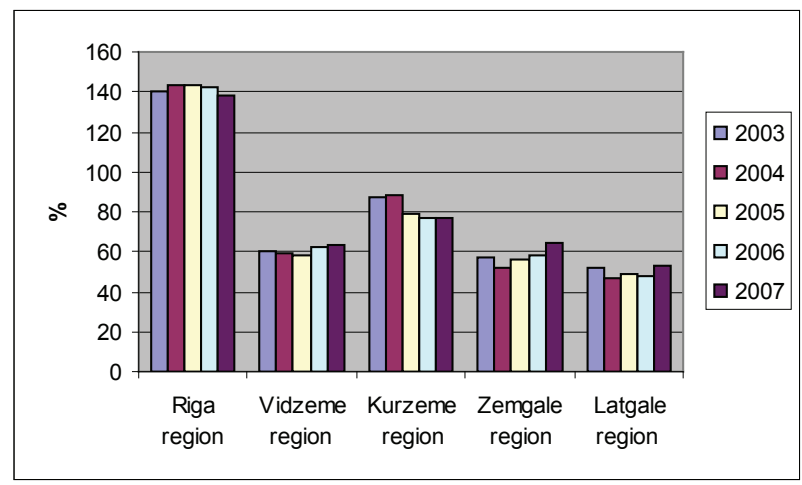

Figure 2. Dynamics of gross domestic product per capita in the regions of Latvia in 2003-2007 in actual prices, $\%$ in comparison to the average indicator in the country (Reǵionu attīstība Latvijā [Development of regions in Latvia] 2009).
In 2008 in Latvia productivity per one employed person was $51.3 \%$ from the respective indicator in the European Union. In Estonia this indicator was $64.7 \%$, in Lithuania $-61.3 \%$. The lowest indicators of productivity in the European Union were among the newest Member States - Bulgaria 36.5\%, Romania $-47.7 \%$. In 2008 the highest indicators of productivity were in Luxemburg - exceeding the average rate by $72.8 \%$, Ireland by $31.5 \%$, and Belgium - by $24.3 \%$ (Eurostat).

During the last decade Latvia has managed to increase productivity per one employed person by $40 \%$, Estonia by $56 \%$, Lithuania by $50 \%$. It is the fastest growth of productivity in Europe. Within the last decade Poland has increased it productivity by $25 \%$, Czech Republic by $19 \%$, Hungary by 7\% (Ukenābele, Pelane, 2010).

Further the authors will conduct the research on productivity according to value added by kinds of economic activities in the regions of Latvia.

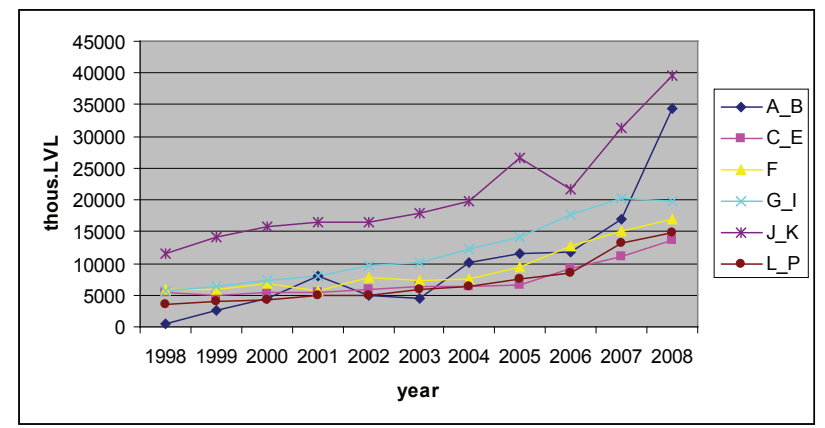

Figure 3. Labour productivity calculating according to the added value by kinds of economic activities (NACE rev. 1.1) in 1998-2008 in Riga region (Authors' calculations according to the information of the Central Statistical Bureau).

Labour productivity tends to increase in all branches calculating it by value added by kinds of economic activities during the last decade in Riga region (see Fig. 3). In Riga region labour productivity in all branches is larger than in other regions. It can be explained by explicit concentration of economic activities and employment in this region. Comparatively more explicit fluctuations in comparison to other regions are observed in labour productivity in agriculture, hunting, forestry and fishing (A, B). In the period of time from 2001 to 2002 productivity sharply decreased, but in 2003 it sharply increased. In other regions these branches have a stable increasing tendency.

In Riga region in 2008 labour productivity in the branch of financial services and real estate transactions reached its peak and was 39617 Ls per one employed person in these areas. It can be explained by rapid increase of crediting and growing demand for real estate.

In Pieriga region (see Fig. 4) in the respective period labour productivity the most significant fluctuations occurred in the field of financial services, real estate transactions (J, K) - in the period of time from 2004 to 2006 it sharply increased, but after 2006 sharply decreased, in the field of mining, manufacturing and related services (C,D, E) changes occurred in the period of time from 2004 to 2008, despite fluctuations labour productivity in these fields in Pieriga region is higher than in other regions (except Riga region), in 2008 it was 11415 Ls per one employed person in 
this field. In the branches of state administration, community, social and personal services (L, M, N, O, P) in Pieriga region labour productivity decreased in 2007.

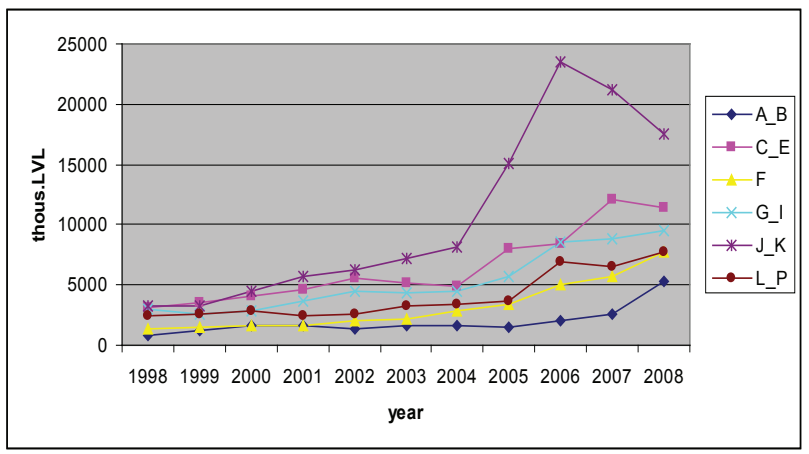

Figure 4. Labour productivity calculating according to the added value by kinds of economic activities (NACE rev. 1.1) in 1998-2008 in Pieriga region

(Authors' calculations according to the information of the Central Statistical Bureau).

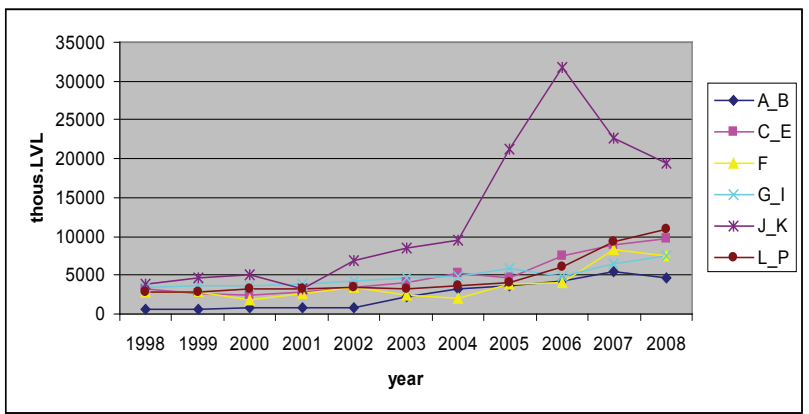

Figure 5. Labour productivity calculating according to the added value by kinds of economic activities (NACE rev. 1.1) in 1998-2008 in Vidzeme region (Authors' calculations according to the information of the Central Statistical Bureau).

In Vidzeme region (see Fig.5) labour productivity faced the most explicit fluctuations in the field of financial services and real estate transactions (J, K), where in 2006 labour productivity was $31662 \mathrm{Ls}$ per one employed person, in 2007 and 2008 productivity decreased in these fields while in Riga, Kurzeme and Latgale regions it sharply increased.

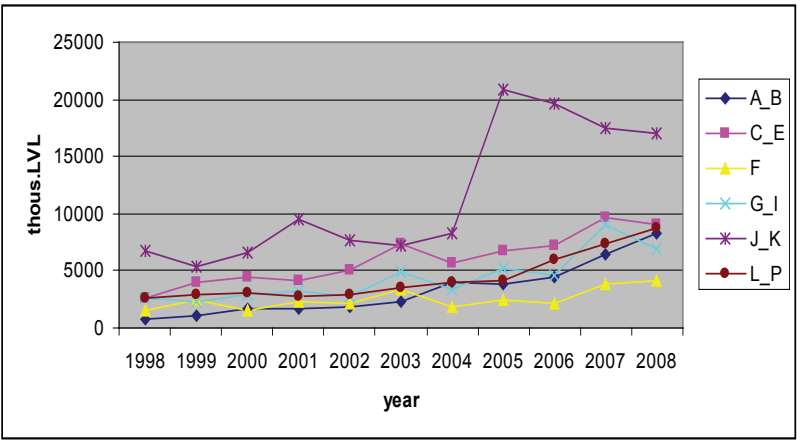

Figure 6. Labour productivity calculating according to the added value by kinds of economic activities (NACE rev. 1.1) in 1998-2008 in Zemgale region (Authors' calculations according to the information of the Central Statistical Bureau).
In Zemgale region (see Fig.6) the most significant fluctuations of labour productivity have taken place in the fields of mining, manufacturing and related services $(\mathrm{C}, \mathrm{D}$, E), construction $(\mathrm{F})$, trade, hotels, restaurants, transport, communication, and repair services $(\mathrm{G}, \mathrm{H}, \mathrm{I})$.

Comparatively high productivity in Zemgale region was observed in agriculture, hunting, forestry and fishing (A, B) in 2008 it comprised 8223 Ls per one employed person in this field. High productivity can be explained by a development agriculture sector in this region.

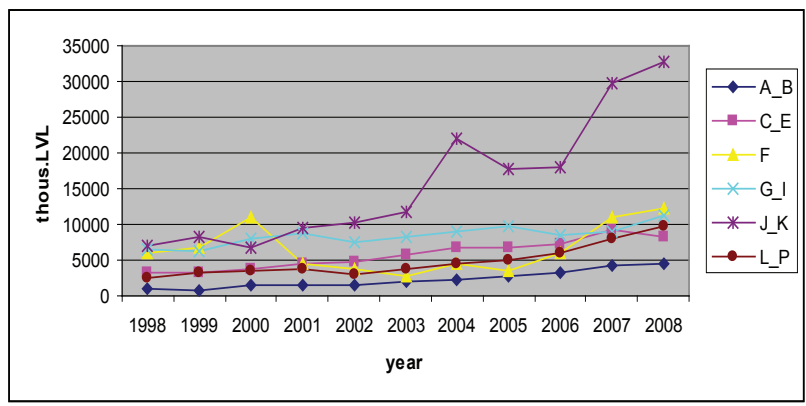

Figure 7. Labour productivity calculating according to the added value by kinds of economic activities (NACE rev. 1.1) in 1998-2008 in Kurzeme region (Authors' calculations according to the information of the Central Statistical Bureau).

In Kurzeme region (see Fig.7) similarly to other regions the most relevant changes were observed in labour productivity the field of financial services and real estate transactions (J, K). In the period from 2000 labour productivity in construction (F) in Kurzeme region had significantly decreased and only in 2007 it reached the level of 2000 having 11022 Ls per one employed person.

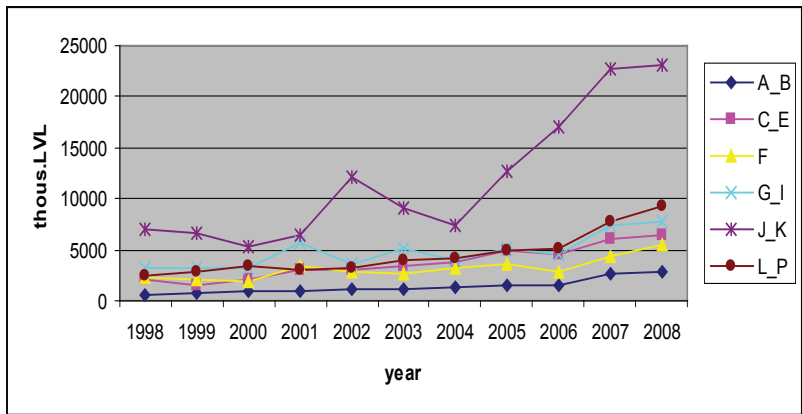

Figure 8. Labour productivity calculating according to the added value by kinds of economic activities (NACE rev. 1.1) in 1998-2008 in Latgale region (Authors' calculations according to the information of the Central Statistical Bureau).

In Latgale region in the respective period the most relevant changes in labour productivity were observed in field of financial services, real estate transactions $(\mathrm{J}, \mathrm{K})$, trade, hotels, restaurants, transport, communication and repair services $(\mathrm{G}$, H, I).

Basing on the calculations of labour productivity according to value added by kinds of economic activities in the period of time from 1998 to 2008 it can be concluded that labour productivity is high, but it is unstable in all regions in the 
field of financial services and real estate transactions (J, K). In the respective period labour productivity increased in the field of trade, hotels, restaurants, transport, communication and repair services $(\mathrm{G}, \mathrm{H}, \mathrm{I})$ in all regions. Comparatively low productivity is the mining, manufacturing and related services $(C, D, E)$. It proves the existence of a development sphere of services having the largest proportion of economically active enterprises and a higher employment rate.

\section{Opportunities for increasing labour productivity}

Eurostat in its research on productivity in the European countries indicates that the highest indicators of productivity are observed in capital intensive industries. In these branches the ration between investments and the number of employed persons has a more significant role; besides, it has been crucially reduced along the development of technologies. Capital intensive branches are mining, manufacturing, real estate transactions, electricity, water and gas supply. But labour intensive branches, for example, services, where a large number of persons is employed (retail sale, hotels, restaurants), have low productivity.

In the regions of Latvia there are comparatively few products having a high value added, which can be exported, thus, it is necessary to develop capital intensive branches resulting in increased labour productivity in regions.

The long-term development strategy of Latvia defines several reasons why labour productivity and also human capital productivity are comparatively low in Latvia at the moment:

a) due to short-term orientation companies and individuals insufficiently invest into development of human capital competences and skills, but significant investments in human capital give return only in the long-run;

b) enterprises and municipalities are afraid of enticing capable and trained employees and are abstain from investing in their development;

c) intensity of using human capital and other barriers (time, money) facilitate solid investments in education neither by employees, nor employers;

d) state implemented support programmes sometimes are overly complicated and changing, but persons having interest have no adequate information and consultative support to make reasonable decisions (Sustainable development strategy of Latvia until 2030).

Each economic activity is based on an enterprise, an institution contributing to the total value added in the branch. The opportunities for increasing labour productivity on the level of an enterprise or an institution are as follows:

1) technical organizational factors - usage of highly effective facilities and progressive technologies (including information technologies), application of computerized systems in projecting, management of the means of labour and technological processes, labour mechanization and computerization, usage of resource saving facilities and technologies, improvement of technical facilities, rationalization of working conditions, etc.

2) personnel factors - timely filling in of workplaces, selection of appropriate employees, facilitation of professional adaptation, training and developing qualification, creation of a stimulating payment system, clear and appropriate division of duties and responsibilities, precise control, improvement of physical and social conditions, etc.

3) product and market factors - changes in omenclature and assortment of products (goods, services) according to the needs of consumers, improvement of product quality, purchase of cheaper product components (raw materials, semi-products, parts) or their purchase in smaller quantities substituting them by one's own work, application of effective marketing to expand the market (Ozoliņa-Ozola, 2009).

In production technical organizational factors are the most significant ones, in services - personnel and product factors. Both for the enterprises of production and services the product market factor is crucial - if there is demand for the goods or services of an enterprise, then there will work and strive to produce (provide services) more.

Productivity does not mean that a product is produced by a fewer employees. It is improvement of goods and services quality in the way individuals would be willing to pay for them. Having a look at the exports of Latvia, it can be concluded that the country has not so many such goods and services, which could be demanded abroad. Enterprises shall focus on the value to be created, not on the number of employees creating it (Ketels, 2009).

As a result of increasing labour productivity the volume of goods or services per one employed person increases, time for production of goods (provision of services) shortens, costs of these goods (services) reduce, and it positively influences the total labour effectiveness High effectiveness ensures private companies more stable position and greater opportunities in the market. For public sector organizations high effectiveness is a real proof that labour is oriented to state welfare interests.

State welfare depends on the value of produced goods and provided services. It is important to make all enterprises understand that future success depends on orientation towards a higher value added. It requires qualified employees and support to enter foreign markets.

\section{Conclusions}

1. Labour productivity is an indicator of labour efficiency - the output in a definite period per one person employed in the state or company. Labour productivity depends on employees' capacity, wish to work and provision with necessary labour facilities and equipment.

2. In 2008 in Latvia productivity per one employed person was $51.3 \%$ from the respective indicator in the European Union. In Estonia this indicator was $64.7 \%$, in Lithuania $-61.3 \%$.

3. During the last decade Latvia has managed to increase productivity per one employed person by $40 \%$, Estonia by $56 \%$, Lithuania by $50 \%$. It is the fastest growth of productivity in Europe.

4. In Riga region labour productivity in all branches is larger than in other regions. It can be explained by explicit concentration of economic activities and employment in this region. Comparatively more explicit fluctuations in comparison to other regions are observed in labour productivity in agriculture, hunting, forestry and fishing. 
5. In Pieriga region labour productivity the most significant fluctuations occurred in the field of financial services, real estate transactions, in the field of mining, manufacturing and related services. In the branches of state administration, community, social and personal services in Pieriga region labour productivity decreased in 2007.

6. In Vidzeme region labour productivity faced the most explicit fluctuations in the field of financial services and real estate transactions, in 2007 and 2008 productivity decreased in these fields while in Riga, Kurzeme and Latgale regions it sharply increased.

7. In Zemgale region the most significant fluctuations of labour productivity have taken place in the fields of mining, manufacturing and related services, construction, trade, hotels, restaurants, transport, communication, and repair services. Comparatively high productivity in Zemgale region was observed in agriculture, hunting, forestry and fishing. High productivity can be explained by a development agriculture sector in this region.

8. In Kurzeme region similarly to other regions the most relevant changes were observed in labour productivity the field of financial services and real estate transactions. In the period from 2000 labour productivity in construction in Kurzeme region had significantly decreased and only in 2007 it reached the level of 2000.

9. In Latgale region in the respective period the most relevant changes in labour productivity were observed in field of financial services, real estate transactions, trade, hotels, restaurants, transport, communication and repair services.

10. Labour productivity is high, but it is unstable in all regions in the field of financial services and real estate transactions.

11. In the respective period labour productivity increased in the field of trade, hotels, restaurants, transport, communication and repair services in all regions. Comparatively low productivity is the mining, manufacturing and related services. It proves the existence of a development sphere of services having the largest proportion of economically active enterprises and a higher employment rate.

12. As a result of increasing labour productivity the volume of goods or services per one employed person increases, time for production of goods (provision of services) shortens, costs of these goods (services) reduce, and it positively influences the total labour effectiveness

13. High effectiveness ensures private companies more stable position and greater opportunities in the market. For public sector organizations high effectiveness is a real proof that labour is oriented to state welfare interests.

14. State welfare depends on the value of produced goods and provided services. Enterprises should to understand that future success depends on orientation towards a higher value added. It requires qualified employees and support to enter foreign markets.

\section{References}

Ekonomikas terminu skaidrojošā vārdnīca [Explanatory dictionary of economic terms]. (2000). Sast. autoru kolektīvs. Rīga: Izdevniecība „Zinātne”, 104. lpp.

Latvija. Pārskats par tautas attīstību 2006/2007. Cilvēkkapitāls: mans zelts ir mana tauta? [Review on national development 2006/2007. Human capital: my gold is my nation?] (2007) LU SPPI un UNDP Latvija, Rīga, 11.lp. ISBN 978-9984-825-13-7

Ulnicāns, E. (2010.) Darba produktivitāte Latvijā pa saimniecisko darbību veidiem 1996.-2009.gadā. [Labour productivity in Latvia by kinds of economic activities in 1996-2009.]. Latgales Tutsaimniecības pētījumi. Sociālo zinātņu žurnāls Nr. 1(2), Rēzekne, 360.-391.p. ISSN $1691-5828$

Ukenābele, I., Pelane, A. (2010) Statistiski produktivitāte neparāda ekonomikas efektivitāti. [Statistically productivity does not show economic effectiveness.] Bilance. - ISSN 1407-5709. - Nr.1 22.-23.lpp.

Ozolina - Ozola, I. (2009). Efektivitāte un produktivitāte [Effectiveness and productivity.]. Biznesa Psihologija. - ISSN 1691-3183. - Nr.19-48.1pp.

Regionu attīstība Latvijā 2009. [Regional development in Latvia, 2009.] Valsts regionālās attīstības aǵentūra. Rīga, 2010. 171 llp.

Lāsmens, K., Tominens, K. (2007). Procesu vadības izcilības kritēriji. [Process management excellence criteria.] Rīga: Biedrība "Latvijas Biznesa konsultantu asociācija".

Ketels, K. (2009). Jācel produktivitāte. [Productivity shall be increased.] Diena, 23.maijs.

Côté, S. (2001.) The Contribution of Human and Sociala Capital. Canadian Journal of Policy Research (ISUMA), vol. 2 (1).

Gomez - Salvador R., Musso A., Stocker M., Turunen J. (2006.) Labour productivity developments in the euro area. Occasional paper series. No.53. On-line: http:// www.ecb.int/pub/html/index.en.html

Bite L., Muška A. Analysis of Labour Environment Factors Impacting the Productivity of Employees. Proceedings of the International Scientific Conference „Economic Science for Rural Development". Resources and Education. Nr.22., Jelgava, 2010. 25.-33.p. ISSN 16913086

Gordon, R. (1997.) Is there a tradeoff between unemployment and productivity growth? In: Snower, D., de la Dehesa, G. (Eds.), Unemployment Policy: Government Options for the Labour Market. Cambridge University Press, Cambridge, UK.

Dew-Becker,I.,Gordon,R.J. (2008.). The role of labourmarket changes in the slowdown of European productivity growth, NBER.

Buchele, R., Christiansen, J., (1999.) Employment and productivity growth in Europe and North America: the impact of Labor Market Institution. Int. Rev. Appl. Econ. 13 (3), 313-332.

Sustainable development strategy of Latvia until 2030. Online: http://www.latvija2030.lv

Gross domestic product from production approach. Definition. On-line: http://www.csb.gov.lv/DATABASE

Total regional value added. Definition. On-line: http://www. csb.gov.lv/DATABASE

Economic activities according to NACE revision 1.1. Definitions. Online: http://www.csb.gov.lv/DATABASE 
Statistical region. Definition. On-line: http://www.csb.gov.lv/ DATABASE

Statistical classification of economic activities in the European Community, NACE revision 1.1. On-line: http://www.csb.gov.lv/node/31668/list

Total value added by kinds of activities in regions. On-line:
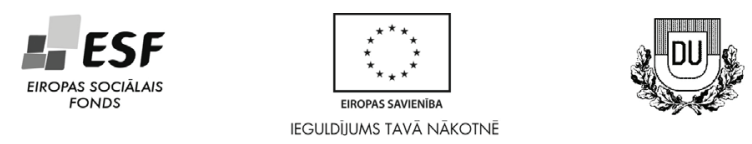

This work has been supported by the European Social Fund within the Project "Support for the implementation of doctoral studies at Daugavpils University" Agreement Nr. 2009/0140/1DP/1.1.2.1.2/09/IPIA/VIAA/015

http://www.csb.gov.lv
Number of employed persons by kinds of economic activities (NACE rev. 1.1) in regions. On-line: http://www.csb.gov. $\underline{\mathrm{lv}}$

Human capital productivity is measured as part of GDP, which consumption versus investments into human capital. On-line: http://www.lisboncouncil.net/initiatives/ human-capital.html/

Productivity. The Key to Competitiveness of European Economies and Enterprises. On-line: http://europa.eu/ legislation_summaries/enterprise/industry/n26027 en.htm

Labour productivity in the European Union states. On-line: http://epp.eurostat.ec.europa.eu/statistics_explained/

The article has been reviewed.

Received in April, 2011; accepted in June, 2011. 